\title{
A Study on the Application of Pigai.org Software in Teaching University-level English Writing - Taking a Freshman Class in Chongqing as an Example
}

\author{
Lei Guo \\ School of Foreign Languages and Literatures, Chongqing Normal University, Chongqing, China
}

\begin{abstract}
Writing correction and feedback are important links in teaching English writing. Both play a vital role in improving students' English writing ability. Pigai.org is an online service that provides correction for teachers of the English language, as well as students. He (2013) believes that traditional teaching methods of English writing have various drawbacks, such as delayed teaching feedback and requiring a heavier workload for teachers. Applying Pigai.org to the teaching of university English writing can not only improve the efficiency of teachers by reducing their workload, but is also able to enhance students' English writing ability and self-writing awareness. Based on the analysis of teaching methodology and the current situation of traditional teaching of university-level English writing, this article uses the writing sample of students as research material, questionnaires and interviews as research methods, so as to explore whether Pigai.org can be used in the teaching of university-level English writing and play a role in improving the effectiveness of university-level English writing.
\end{abstract}

Index Terms—Pigai.org, writing ability, self-writing awareness

\section{INTRODUCTION}

Among the five basic abilities of university English, the cultivation of a student's writing ability has always been the greatest focus and the greatest difficulty (Quan, 2012). John (2014) says that since the late 1970s, English education began to flourish in China, and English started to be regarded as a useful means for the modernization and development of China. After more than 40 years of development, English has become a foreign language that Chinese students must master. Learning English is a regular aspect of each student's learning experience throughout their childhood education. English has been a compulsory course for students in the last 30 years. As opposed to in the past, English teaching no longer solely focuses on students' words and grammar, but also the comprehensive development of listening, speaking, reading and writing skills (Yang, 2015). Writing plays an important role in the high school entrance examination, college entrance examination and postgraduate entrance examination. Since the implementation of the National University English Teaching Reform in 2004, the use of multimedia and technology for English teaching has gradually become popular (Wang, 2015). The advent of the information era has changed the original teaching model that was originally largely dependent on the teaching of teachers. It has also enabled students to learn English through more means. English writing ability is a manifestation of the ability to use English comprehensively. However, there are many problems concerning teaching English writing in Chinese universities. For example, there are few English class hours, too many students in one class and no professional writing textbook. Therefore, current Chinese university students generally have a low English writing level. The average student is not interested in learning English writing, and also suffers from a lack of personalization in learning methodology. In a typical English writing class using traditional methodology, teachers teach, and students memorize and complete practice exercises and activities. It is difficult for students to increase their interest in learning English writing. In addition, after students have completed their writing assignment, teachers need a lot of time to properly and thoroughly make corrections. As a result, students cannot get timely writing feedback, and, thus, make the students lose interest in English writing. The Ministry of Education promulgated the standard requirements for university English courses in 2007. It clearly states that teachers should make full use of opportunities provided by multimedia and technology, support modern technology, and adopt English teaching models based on computers and classrooms, in order to improve the current single-mode methodology of teaching in teaching university-level English (Chen, 2014). In recent years, many domestic scholars have discussed the use of computers and network technology in teaching English writing. With the emergence of the Pigai.org, the teaching of university-level English saw the ushering in of an opportunity for change. Pigai.org achieved the combination of modern information technology and traditional teaching. It also solved many problems that were unavoidable in the traditional teaching method of English writing. It can grade students' writing in a brief amount of time and make comments, which effectively improves the efficiency of teachers in correcting their students' writings. At 
the same time, through timely feedback and sentence-by-sentence commenting, students can quickly understand their own problems, thereby improving students' English writing ability and, to some extent, stimulating students' enthusiasm for learning English. Based on this hypothesis, I took an English teaching class for freshman in Chongqing as an experimental subject to study whether the teaching of English writing based on Pigai.org can improve students' English writing ability and interest in learning English.

\section{The Current Situation of the Teaching OF University-LEVEL ENGLiSH Writing}

Currently, universities in China generally have English courses unsuitable for students. At most universities, there are two classes per week. This is far from the needed amount of class-time for learning English. Most universities in China require students to pass CET4 (College English Test Band 4), in order to obtain their bachelor's degree, most students only care about the scores of the test. At the same time, due to time constraints, many universities do not offer English writing classes, thus, students can only study English writing in addition to listening and speaking classes. In addition, Shi ( 2012 ) argues that in most universities in China, there are usually more than 50 students in an English class. The time that a teacher could give to each individual student is less than one minute on average. The teacher's teaching methods are also relatively simple. They tell students the writing strategy in the class, and then let students practice. Then, the teacher collects the students' writing in order to make manual corrections, which costs the teacher a lot of time. Due to the influence of energy distribution, the score of the writing of the same level may be uneven (Ding,2009). Moreover, there is a time gap between the completion of the writing and the feedback from the teacher. Students are likely to have forgotten the writing they wrote during that time, which is not conducive to the students' ability to modify the writing in time and strengthen their memory. In addition, there are also cases where teachers are not serious about correcting their writings. The biggest current problem in teaching English writing is that both teachers and students put a lot of energy into it, but the results are not improving. Therefore, it is necessary to study the teaching of English writing in university in-depth, as well as to adopt new teaching methods.

\section{InTRODUCTION AND AdVANTAGES OF PIGAI.ORG}

With the deepening of the reform of the university English teaching mode, multimedia technology and network teaching platforms have been welcomed by more and more teachers and students (Yang, 2011). The network teaching platforms change the traditional teaching mode. They can better stimulate the learner's enthusiasm for learning. Outside of the classroom, students can learn English in any place at any time with the help of an internet network, so that the learning efficiency of students can be improved. Pigai.org is an online system that automatically corrects English writings with a computer. It is a new type of online writing service system that provides teachers and students with online writing correction services in the form of SAAS (Software as a Service). It provides students with a new type of writing mode, promptly conducts students' writing feedback to stimulate students' enthusiasm for writing and helps teachers better understand students' writing situation. The operational principle of Pigai.org is to compare the distance between the student's writing and the standard corpus, and map it into components and comments through a certain algorithm. Finally, teachers can view the student's score and write comments to students. The emergence of Pigai.org has effectively reduced the workload of English teachers in universities, and it has also allowed students to view their scores and writing errors in time, so that students can modify their writing in time and strengthen their memory. The combination of machine correction and teacher correction can provide rapid and accurate feedback to students' English writing.

The advantages of Pigai.org are as follows:

(1) Easy to use

The operation of Pigai.org is extremely simple. Teachers only need to log in at Pigai.org, arrange the writing and specify the requirements, and the writing number will be automatically generated. Students only need to search for the writing number to complete the writing online. 


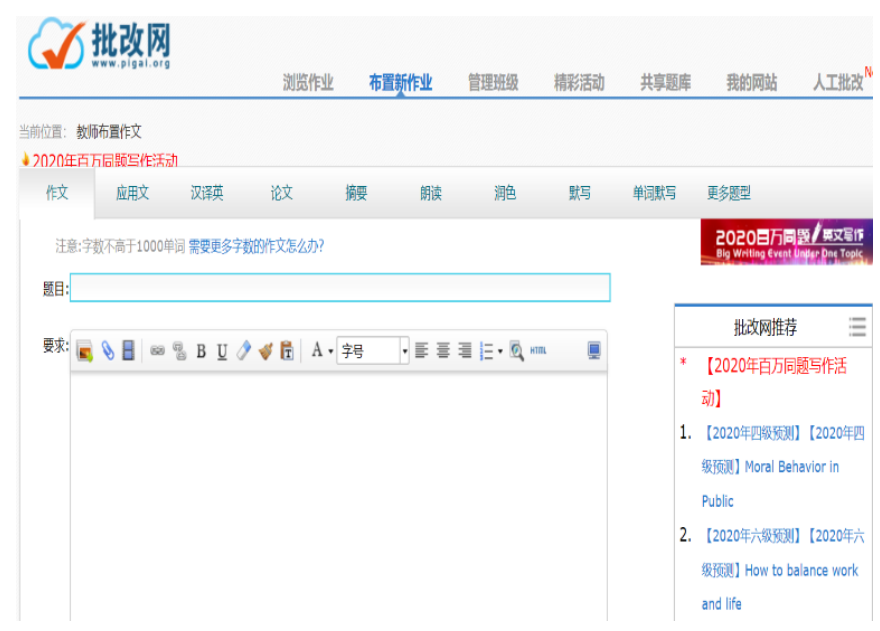

Figure 1 the interface of writing assignment

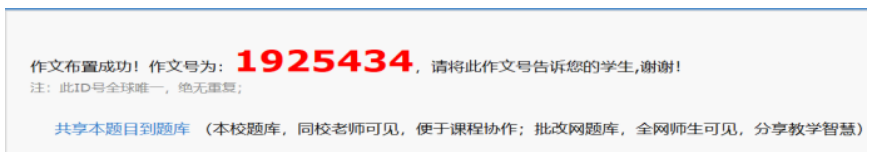

Figure 2 the interface of sequence of writing

(2) Timely feedback

Students will receive systematic feedback soon after submitting their writing, which includes their total points, vocabulary, sentences, structure, and chapter content.

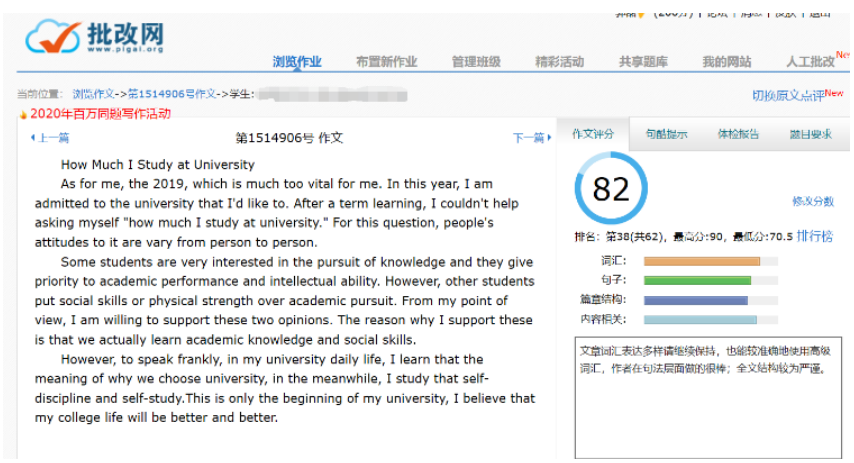

Figure 3 the interface of scoring and commenting

(3) Reviewing by sentence

In addition to feedback to the student's total score and words, sentences and other grades, Pigai.org also provides a function of sentence by sentence commentary, so that students can know their writing problems. It also provides students with synonyms, recommended expressions, etc.

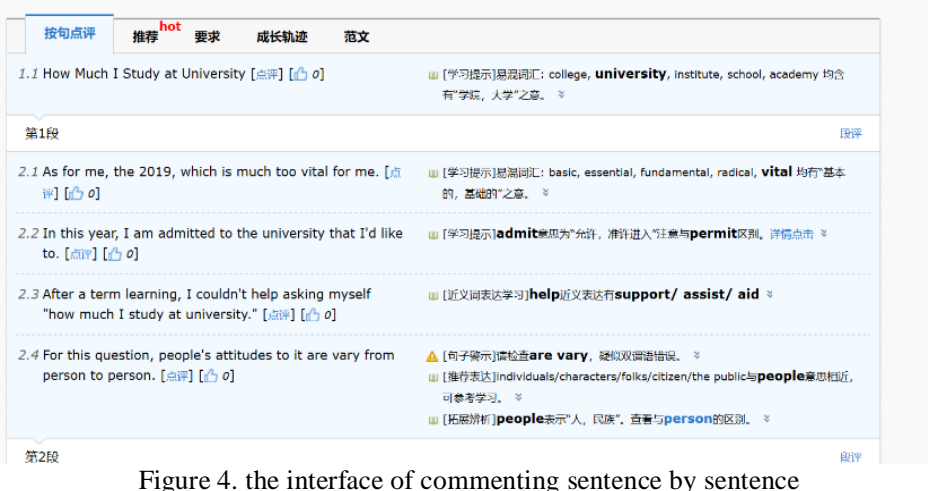

(4) Plagiarism detection 
After students submit the writing, Pigai.org will judge the similarity of the article and other articles in the corpus according to its own prediction database. When there is too much similarity, Pigai.org will remind the teacher and provide the teacher with the percentage of similarity. Teachers can also view the similar parts of the two articles and the sources of the plagiarized articles.

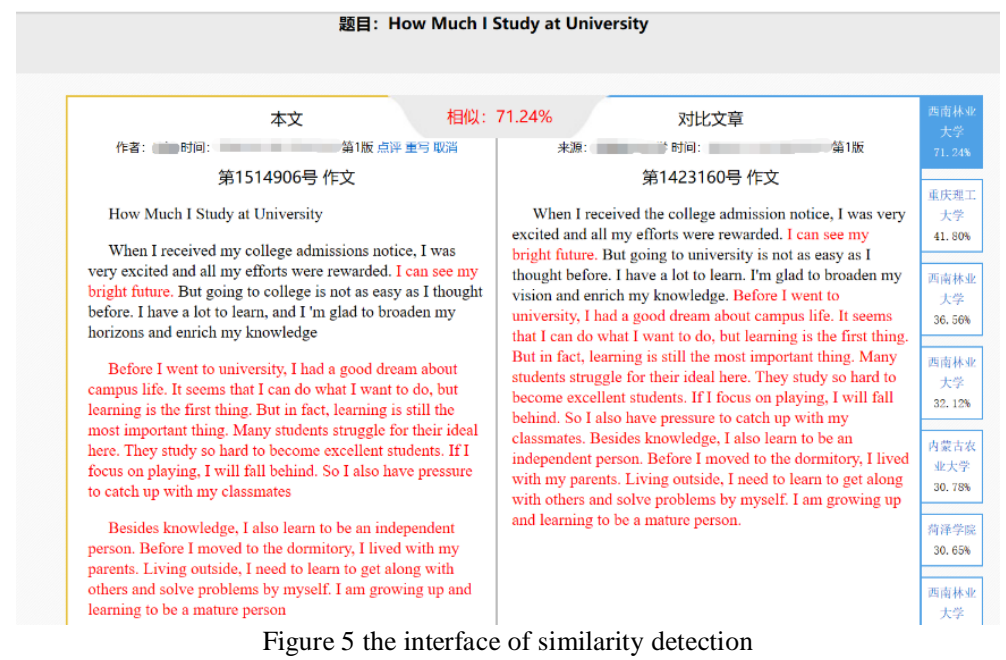

(5) Providing error statistics

After a student submits their writing, the system will automatically generate the error statistics of the student's writing, including errors in spelling, parts of speech and collocation. The system can also provide complete writing statistics for the whole class.
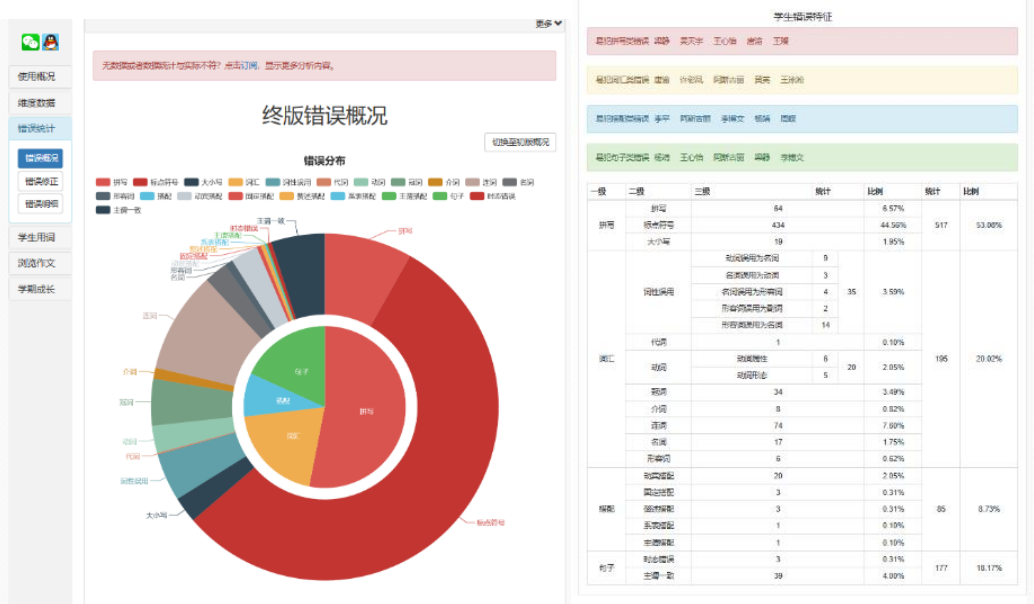

Figure $6 \& 7$ the interface of error statistics

\section{The Application of PIGAI.org In Teaching University-LEVEl ENGLish Writing}

With the continuous development of science and technology, more new technologies have been applied to university-level English teaching, such as Pigai.org, FIF Speaking Training APP, etc. These kinds of software have many inherent advantages, such as the huge database support behind them, and no restrictions regarding time and geography. At present, many universities in China are using Pigai.org as an automatic evaluation system for students' writing. Their functions include automatic recognition and error evaluation of common errors such as words and grammar in students' writings, marking the incorrect expressions in the text and giving writing scores and suggestions for modification. It also provides students with extended training of specific knowledge points. To a certain extent, it can promote university-level English teaching and facilitate students' independent learning. However, Pigai.org also has many shortcomings. For example, Pigai.org can only evaluate students' writing and provide suggestions for modification in terms of vocabulary and grammar. However, the evaluation of the structure and logic of the writing is rarely involved in whether the semantics of the writing are relevant. Based on this, I launched my experimental research.

\section{A. Research Problem}


The main questions in this research are: (1) How well do students accept the use of Pigai.org for English writing? (2) Can Pigai.org effectively improve students' writing skills for university-level English writing? (3)Can Pigai.org effectively stimulate students' interests in learning English writing?

\section{B. Research Object}

All foreign language classes in my university are required to use Pigai.org to write. The research object of this study is a freshmen class in a university in Chongqing. The class has a total of 62 students from four different administrative classes. Taking the students in this class as the research object, it mainly compares the scores of the students before and after using Pigai.org and the students' attitudes towards using Pigai.org to teach English writing. After investigation, before this experiment, only 2 students in this class used Pigai.org, and the remaining 60 students did not use Pigai.org. Before the experiment, the students were asked to complete a writing task on Pigai.org. And they were required not to make any correction after submitting. This is used as an original score for students to prove the effectiveness of the experiment.

\section{Research Tools}

In response to my research questions, this study mainly used sample analysis, questionnaire surveys, and interviews, in order to collect and organize data.

There is no specific English writing course for experimental class. The only task related to writing is writing after the end of each precision unit. Before the end of each unit, students have 45 minutes to learn English writing, and then completed the writing assignments arranged on Pigai.org within a week. During this period, the students could receive the corrections that were made at Pigai.org. After receiving the feedback, they could repeatedly correct what they wrote to obtain a higher score. From September 27, 2019 to January 1, 2020, students have completed a total of four essays. The average score of the writing task class assigned before the start of the experiment was 74.5 points.

\section{Research Process}

From September 27, 2019 to January 1, 2020, students were required to complete a total of four writing assignments. The average score for the writing task class assigned before the experiment began was 74.5. From October 16, 2019 to October 23, 2019, the students were required to complete their first writing task: My View on Academic Success. According to data from Pigai.org, the average score of the writing was 79.3 points. The number of students scoring over 80 was 32. The number of students with total instances of correction over 10 was 22 . The number of students with instances of corrections over 5 was 43 . The number of students with instances of corrections over 3 was 58.

From November 4, 2019 to November 11, 2019, students were required to complete the second writing task: My View on Diversity. According to data from Pigai.org, the average score of the writing was 81.4 points. Average scores rose 2.1 points over the first writing. The number of students scoring over 80 was 48 , with 16 more students than last time. The number of students with correction times over 10 was 9 . The number of students with correction times over 5 was 33 . The number of students with correction times over 3 was 45 . The number of students with correction times was lower than last time.

From December 2, 2019 to December 9, 2019, students were required to complete the third writing task: My View on Compromise. According to data from Pigai.org, the average score of the writing was 82.6 points. Average scores rose 1.2 points over the second writing task and 3.3 over the first writing task. The number of students scoring over 80 was 49, with 1 more student than last time. The number of students with correction times over 10 was 7 . The number of students with correction times over 5 was 27 . The number of students with correction times over 3 was 45 . The number of students with correction times was lower than the previous time.

From December 23, 2019 to December 30, 2019, students were required to complete the fourth writing task: How Much I Study at University. According to data from Pigai.org, the average score of the writing was 83.4 points. Average scores increased by 0.8 points over the third writing task, 2 points over the second writing task and 4.1 points over the first writing task. The number of students scoring over 80 was 52 . with 3 more students than last time. The number of students with correction times over 10 was 5 . The number of students with correction times over 5 was 20. The number of students with correction times over 3 was 40 . The number of students with correction times was lower than the third task. The number of modifications is on a downward trend form the four writing tasks. 
TABLE 1

TABLE OF WRITING FEEDBACK

\begin{tabular}{|c|c|c|c|c|c|c|c|}
\hline Time & Writing topic & $\begin{array}{l}\text { Average } \\
\text { score }\end{array}$ & $\begin{array}{l}\text { The } \\
\text { number } \\
\text { of } \\
\text { students } \\
\text { scoring } \\
\text { over } 80\end{array}$ & $\begin{array}{l}\text { The } \\
\text { number of } \\
\text { students } \\
\text { with } \\
\text { correction } \\
\text { times over } \\
10\end{array}$ & $\begin{array}{l}\text { The } \\
\text { number of } \\
\text { students } \\
\text { with } \\
\text { correction } \\
\text { times over } \\
5\end{array}$ & $\begin{array}{l}\text { The } \\
\text { number of } \\
\text { students } \\
\text { with } \\
\text { correction } \\
\text { times over } \\
3\end{array}$ & $\begin{array}{l}\text { Figures } \\
\text { of rise in } \\
\text { average } \\
\text { scores }\end{array}$ \\
\hline $2019.10 .16-2019.10 .23$ & $\begin{array}{l}\text { My View on } \\
\text { Academic } \\
\text { Successful }\end{array}$ & 79.3 & 32 & 22 & 43 & 58 & 4.8 \\
\hline 2019.11.4-2019.11.11 & $\begin{array}{l}\text { My View on } \\
\text { Diversity }\end{array}$ & 81.4 & 48 & 9 & 32 & 45 & 2.1 \\
\hline $2019.12 .2-2019.12 .9$ & $\begin{array}{l}\text { My View on } \\
\text { Compromise }\end{array}$ & 82.6 & 49 & 7 & 27 & 45 & 1.2 \\
\hline 2019.12.23-2019.12.30 & $\begin{array}{lr}\text { How Much I } \\
\text { Study } & \text { at } \\
\text { University } & \end{array}$ & 83.4 & 52 & 5 & 20 & 40 & 0.8 \\
\hline
\end{tabular}

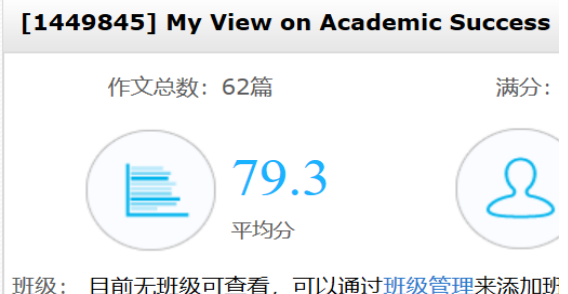

[1497650] My View on Compromise

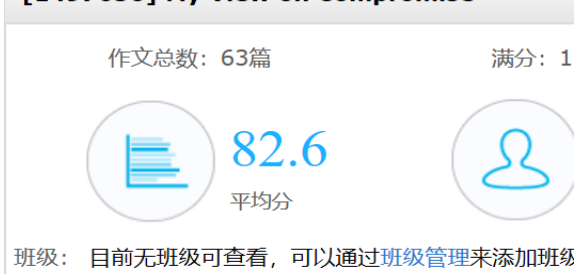

[1469659] My View on Adversity

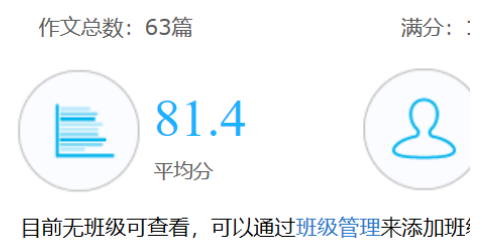

[1514906] How Much I Study at University

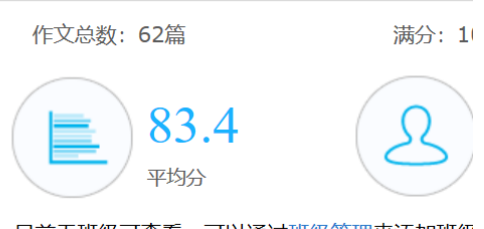

Figure 8-11 Screenshots of average writing score

In addition to using the automatic scoring system of Pigai.org, I also checked and analyzed the four essays of some of the students, and I found that their vocabulary and grammatical errors were reduced to a certain extent. There was a certain degree of improvement. At the same time, after the completion of the third writing training, I randomly selected 10 students for a simple interview, mainly to ask the students' acceptance of the use of Pigai.org for teaching, whether they themselves think that their writing level is improved by using Pigai.org and whether Pigai.org can effectively stimulate students' interest in learning English writing.

After completing all the essay training for the semester, I conducted a brief questionnaire survey on 62 subjects in the class, using a semi-open form and the Likert scale. After the modification, the corresponding reliability and validity analysis was carried out. The topic revolved around the students' views on the use of Pigai.org for teaching writing, whether they, themselves, think that their writing level has been improved after using Pigai.org, and whether Pigai.org can stimulate their own writing interests.

\section{CONCLUSIONS AND DEFICIENCIES}

During the interviews, 8 out of 10 students were supportive of using Pigai.org for writing. Among them, 7 students made it clear that after using Pigai.org, their English writing level had improved, and 6 students said that using Pigai.org increased their interest in learning how to write effectively using English. The results of the questionnaire survey are similar to the results of the interview. Among all the valid questionnaires, $76 \%$ of the students chose "I think Pigai.org has a positive effect on my English writing study", and about $72 \%$ of the students chose "I think the quality of my English learning has improved after using Pigai.org ", and about 63\% of the students chose "I think Pigai.org has increased my interest in learning English writing." In addition, I also designed the correction content that the students wanted in the questionnaire, and I found that $45 \%$ of the students chose to modify the grammatical errors. Through 3 months of thematic writing training, it is not difficult to find that before teachers guide students to use the Pigai.org for writing, the average score for students' writing on Pigai.org was below 75 points. Through the writing exercises on Pigai.org, the students' writing scores began to increase. Although the subsequent score growth slowed down, they still showed an increasing trend. The number of people with a score of 80 or more gradually increased. This shows that students' vocabulary and grammatical errors gradually decreased, and their English writing level gradually improved. At 
the same time, when the student's score rose, the number of students with instances of correction gradually decreased. Students got higher writing scores with fewer corrections, which also prove that the students' English writing level had improved after the intervention of Pigai.org. The improvement of students' English writing ability is not only reflected in the scores of Pigai.org and the number of revisions. From the interview after the third essay training and the questionnaire survey after the last essay training, most of the students thought that the use of Pigai.org had had a positive effect on their English writing, and most students also expressed the use of Pigai.org had improved their English writing skills and interest in learning English writing. In summary, through research and investigation, it is found that the use of Pigai.org can effectively improve students 'writing skills in university-level English writing teaching. Pigai.org can effectively stimulate students' interest in learning English writing. Of course, there are still many shortcomings in this study. First, because the experiment lacks a control group, the role of Pigai.org in students' English writing can only be judged by the students' scores before and after using Pigai.org, interviews and questionnaires, which may lead to a certain deviation from the actual results. At the same time, in this experiment, I use the average score of the students, and does not specifically analyze and elaborate the learning situation of each student. This may also lead to a certain deviation between the conclusions of the experiment and the real results. In the process of using Pigai.org and the students' questionnaires, although the correction network has many advantages, it also has many shortcomings. Among them, $71 \%$ of the students said that although Pigai.org provided grammar and vocabulary feedback, there was less feedback on the content and logical connection. $21 \%$ of the students said that the revision opinions given by Pigai.org are relatively general and almost the same. For example, even if they knew the mistakes, they did not know how to modify them. In addition, the scores of the review are mechanized, it makes the scores not objective enough. Many students 'revised scores are even lower than before. This is a problem with Pigai.org.

\section{SOME Suggestions FOR PIGAI.orG AND TEACHERS}

In response to the above problems, I propose the following suggestions for Pigai.org: First, Pigai.org must update the corpus over time and introduce more foreign articles to meet the needs of teachers and students at different levels. Second, Pigai.org must constantly improve its own system. Reviewing articles is not only able to pay attention to the use of students 'word grammar, but also to consider whether the article's semantics are relevant, and whether the structure and logic of the article are clear. Third, Pigai.org can also create more practical functions, such as instant interaction between teachers and students. After the manual correction by a teacher, students will receive the feedback of the teacher from Pigai.org immediately. After receiving the feedback of the teacher, students can use the instant interaction function to discuss their problems in writing with teachers, so as to achieve the goal of improving students' writing ability. Fourth, Pigai.org can provide students with some model writing after they submit their writing based on its database, in order to make students find their own shortcomings in time and improve their writing ability.

As for teachers, because machines can't replace the wisdom of the human brain, they cannot completely rely on the correction using Pigai.org to teach English writing. In order to reduce the negative impact of inappropriate comments of Pigai.org, the machine correction of Pigai.org also needs to combine with manual review and peer review. In addition, teachers should find the most effective way when using manual correction, correction and machine correction. Only in this way can the students' English writing level be really improved.

\section{REFERENCES}

[1] Chen Feng. (2014). A Study on the Application of "pigai.org" Software in English Writing. Journal of East China University of Technology (Social Science), 33, 173-177.

[2] Ding Wangdao. (2009). A Handbook of Writing. Beijing: Foreign Language Teaching and Research Press.

[3] He Xuliang. (2013). Reliability and Validity of Assessment by Pigaiwang on College Students' writings. Modern Educational Technology, 23, 45-47.

[4] John Langan. (2014). College Writing Skills with Readings. Beijing: Foreign Language Teaching and Research Press.

[5] Quan Dong. (2012). Use Writing Programs to Promote Student Writing Skills-An Empirical Report from College English Teaching. Modern Educational Technology, 8, 80-84.

[6] Shi Xiaoling. (2012). A tentative Study on the Validity of Online Automated Essay Scoring Used in the Teaching of EFL Writing-Exemplified by http//www.pigai.org. Modern Educational Technology, 22, 67-71.

[7] Wang Zhe. \& Zhang Yue. (2015). Big Data Methodology and EFL Teaching Innovation-A Case Study of One Million-odd EFL Writings on the Same Topic. Technology Enhanced Foreign Language Education, 5, 3-8.

[8] Yang Xiaoqiong. \& Dai Yuncai. (2015). An Empirical Study on College English Autonomous Writing Teaching Model Based on www.pigai.org. Technology Enhanced Foreign Language Education, 2, 17-23.

[9] Yang Yonglin. \& Quan Dong. (2011). Application of Cognitive Theory to Information Technology-A Fruitful Way to the Teaching of English Writing. Technology Enhanced Foreign Language Education, 142, 41-57.

Lei Guo was born in Sichuan, China in 1995. Now, he is a postgraduate student in Chongqing Normal University, China. His research interests include foreign language teaching and cognitive linguistics. 